\title{
PRINSIP KESOPANAN DALAM TINDAK TUTUR \\ TRANSAKSI JUAL BELI DI PASAR MINGGUAN DESA TEBABAN \\ KECAMATAN SURALAGA: KAJIAN PRAGMATIK
}

\author{
(THE PRINCIPLE OF POLITENESS IN SPEECH ACTING IN BUYING AND \\ SELLING TRANSACTION IN TEBABAN VILLAGE WEEKLY MARKET, \\ SURALAGA DISTRICT: PRAGMATIC STUDY)
}

\author{
Herman Wijaya \\ Universitas Hamzanwadi \\ Email: wijaya.herman33@yahoo.com
}

Diterima: 3 Februari 2019; Direvisi: 27 Mei 2019; Disetujui: 18 Juni 2019

\begin{abstract}
Abstrak
Komunikasi akan berjalan dengan baik dan lancar jika orang-orang yang di dalamnya memiliki pemahaman yang sama dengan apa yang dikomunikasikan. Tujuan penelitian ini meneliti prinsip kesopanan dalam bertindak tutur transaksi jual beli di Pasar Mingguan Tebaban. Metode penelitian ini menggunakan metode deskripsi kualitatif. Teknik pengumpulan data menggunakan teknik pengamatan/observasi, cakap/wawancara, dan sadap/rekam, agar data dari percakapan antara peneliti dengan dengan penjual di Pasar Mingguan Tebaban ini lebih representatif. Berdasarkan penelitian yang sudah dilakukan, peneliti menemukan bahwa dalam penerapan prinsip kesopanan lebih banyak dilanggar oleh calon pembeli dalam bertutur di dalam bertransaksi. Pertuturan yang wajar akan terbentuk jika penutur dan lawan tutur sama-sama menyadari bahwa ada kaidah-kaidah yang mengatur tindakannya. Teori prinsip kesopanan dengan berbagai maksim memberikan tuntunan kepada mitra tutur bagaimana bertutur secara sopan dan santun.
\end{abstract}

Kata Kunci: prinsip kesopanan, tindak tutur

\begin{abstract}
Communication will run well and smoothly if the people in it has the same understanding as what is communicated. The purpose of this study is to examine the principle of politeness in speech acting in buying and selling transaction at the Tebaban Weekly Market. This research method uses a qualitative description method. Data collection techniques used observation, interview, and recording techniques, so that data from conversations between researchers and sellers at the Tebaban Weekly Market was more representative. Based on the research that has been done, the researchers found that in applying the principle of Politeness more violated by prospective buyers in speaking in the transaction. A reasonable formulation will be formed if the speaker and the opponent speak together realize
\end{abstract}


that there are rules that adjust their actions. The theory of politeness with various maxims gives guidance to the speech partner how to speak politely and good manners.

Keywords: principles of politeness, speech acts

\section{Pendahuluan}

Berbahasa adalah aktivitas sosial. Seperti halnya aktivitas-aktivitas sosial yang lain, kegiatan berbahasa baru terwujud apabila manusia terlibat di dalamnya. Dalam berbicara, penutur dan mitra tutur sama-sama menyadari bahwa ada kaidah-kaidah yang mengatur tindakannya, penggunaan bahasanya, dan interpretasiinterpretasinya terhadap tindakan dan ucapan lawan tuturnya. Setiap peserta tindak tutur bertanggung jawab terhadap tindakan dan penyimpangan terhadap kaidah kebahasaan dalam interaksi. Dalam kehidupan seharihari, manusia tidak pernah bisa lepas dari proses komunikasi, baik verbal maupun nonverbal. Komunikasi dilakukan untuk mempermudah manusia menyelesaikan pekerjaan mereka.

Salah satu standar bertingkah laku dalam norma sosial adalah berbicara dengan sopan. Berbicara sopan merupakan aturan perilaku yang ditetapkan dan disepakati bersama oleh suatu masyarakat tertentu dalam berperilaku sosial. Dalam menyampaikan informasi, seseorang harus memperhatikan norma-norma budaya yang ada dalam masyarakat. Jika tata cara berkomunikasi seseorang tidak sesuai dengan norma-norma budaya yang ditaati atau dipatuhi, orang ini akan mendapatkan nilai negatif dari orang lain, misalnya dituduh sebagai orang yang sombong, angkuh, tak acuh, egois, tidak beradab, bahkan tidak berbudaya. Sopan santun dalam berbahasa tercermin dalam tata cara berkomunikasi lewat unsur verbal. Kesantunan berbahasa secara verbal adalah segala unsur kesantunan yang berkaitan dengan masalah bahasa. Menurut Pranowo (2009:9), ada beberapa unsur verbal yang menyebabkan kesantunan dalam berbahasa. Unsur-unsur tersebut meliputi pemakaian diksi yang tepat, pemakain gaya bahasa yang santun, pemakaian struktur yang baik dan benar, penggunaan pilihan kata honorifik atau sapaan penghormatan, 
dan panjang pendek tuturan. memiliki makna literal, tetapi juga Kesantunan berbahasa memiliki makna nonliteral. Salah satu contoh kriteria-kriteria kesantunan yang harus dari proses komunikasi verbal tersebut ditaati oleh para peserta pertuturan. adalah dalam transaksi jual beli antara Kriteria-kriteria tersebut membimbing para peserta pertuturan untuk penjual dan pembeli. Pada suatu tempat menciptakan komunikasi yang efektif, terhindar dari kesalahpahaman, dan juga tidak menyinggung perasaan orang lain. Para ahli mencoba menjelaskan kriteria-kriteria kesantunan dalam berkomunikasi dengan cara menulis teori kesantunan berbahasa.

Dalam suatu peristiwa, komunikasi akan berlangsung apabila orang-orang yang di dalamnya memiliki kesamaan persepsi atau makna mengenai suatu hal yang dikomunikasikan. "Bahasa sebagai batasan sederhana dapat dikatakan sebagai suatu sistem vokal simbol yang bebas yang dipergunakan oleh anggota masyarakat untuk berkomunikasi atau berhubungan." (Aslinda dan Syafyahya, 2010:92). Proses komunikasi tersebut dilakukan, baik secara verbal maupun nonverbal. Pada komunikasi verbal, tuturan merupakan hal terpenting saat proses komunikasi terjadi. Hal ini disebabkan tuturan merupakan tindak praktik sosio-budaya yang tidak hanya perbelanjaan, seperti Pasar Mingguan Tebaban, terdapat berbagai ragam jenis barang yang dijual oleh setiap orang atau penjual. Seperti, penjual prabotan dapur, pakaian, buah, burung, makanan ringan (snack), kaca mata, dan penjual sayur.

Adapun yang paling menonjol percakapannya dalam transaksi jual beli di pasar Pasar Mingguan Tebaban ini adalah percakapan yang terjadi antara penjual dan pembeli sayur. Dalam transaksi jual beli, komunikasi yang baik akan menghasilkan transaksi yang baik pula. Oleh sebab itu, dibutuhkan pemahaman yang sama akan makna tuturan, baik dari pihak penjual maupun dari pihak pembeli itu sendiri. Untuk memahami makna literal maupun nonliteral dalam transaksi jual beli, diperlukan penjelasan fungsional, eksplisit, dan kontekstual yang lazimnya tidak terjangkau oleh penjelasan linguistik formal. Salah satu cara untuk memahami makna tuturan tersebut adalah dengan memahami makna dari percakapan atau tuturan itu 
sendiri. Berdasarkan pengamtan di Pasar Mingguan Tebaban, banyak ditemukan pelanggaran prinsip kesopanan dalam berkomunikasi. Hal ini disebabkan oleh perbedaan maksud antara penjual dan pembeli. Pelanggaran yang lain juga disebabkan oleh adanya variasi tindak tutur pada para pedagang berdasarkan konsep kesantunan dan kerjasama. Variasi bahasa itu muncul dilatar belakangi oleh status sosial dan pendidikan yang terdapat di setiap masyarakat bahasa. Sebagaimana yang dikemukakan (Sumarsono, 2010:143--144), bahwa dalam membangun kerjasama dalam percakapan, para partisipan masih perlu membangun hubungan yang lebih baik lagi. Wujudnya ialah tata krama atau kesantunan. Apapun yang namanya kerjasama pasti memerlukan aturan main untuk menghindari ketersinggungan atau bahkan konflik yang pada gilirannya akan menyebabkan komunikasi menjadi terganggu dan macet.

Mengacu pada pendapat tersebut, para pedagang harus memperhatikan bahasa yang digunakan agar pembeli tidak merasa tersinggung bahkan merasa dilecehkan oleh bahasa yang digunakan, sebagaimana yang peneliti ketahui bahwa mayoritas penduduk masyarakat Tebaban sangat menjunjung tinggi arti dan makna bahasa yang dimiliki. Kendala situasi dan kondisi mitra tutur pada saat terjadi interaksi antara penjual dengan pembeli juga dapat memengaruhi perbedaan maksud tersebut. Perlu adanya sebuah kajian implikatur dalam memahami makna tuturan pada transaksi seperti ini, yakni komunikasi antara pedagang dan pembeli untuk mencegah kesalahan-kesalahan maksud dari suatu tuturan.

\section{Landasan Teori \\ 2.1 Tindak Tutur}

Peristiwa tutur dan tindak tutur merupakan dua gejala berbahasa yang terdapat pada suatu proses, yakni proses berkomunikasi. Aslinda dan Syafyahya (2010:33) mengatakan “jika peristiwa tutur merupakan gejala sosial yang menyangkut adanya pihak-pihak yang bertutur dalam situasi dan tempat tetentu, tindak tutur cendrung sebagai gejala individu yang bersifat psikologis dan ditentukan oleh kemampuan bahasa penutur dalam menghadapi peristiwa tertentu. Perisiwa tutur lebih lebih menitikberatkan pada makna atau arti tindak (event-nya), sedangkan 
tindak tutur lebih menitikberatkan pada makna atau arti tindak (act) dalam suatu tuturan." Pandangan Austin dalam Louise (2007:08) tentang bahasa telah menimbulkan pengaruh yang besar di bidang filsafat mauapun linguistik. Pandangan-pandangan ini telah mencapai filosifis sebagai bagian dari gerakan bahasa biasa yang pernah popular dalam filsafat. Pada masa-masa selanjutnya, pandangan-pandangan ini telah diadopsi dan dikembangkan secara aktif oleh para ahli bahasa. Banyak di antaranya sedang mengalami kecemasan yang semakin mendalam terhadap linguistik Chomsky.

Berpijak pada semua isu dalam teori umum tentang penggunaan bahasa, teori tindak tutur mungkin merupakan isu yang paling luas menarik minat. Para psikolog mengemukakan bahwa pemerolehan konsep-konsep yang melandasi tindak tutur mungkin merupakan prasayarat bagi pemerolehan bahasa pada umumnya. Para filosof melihat potensi teori ini untuk diterapkan, antara lain, pada ajaran etika, sementara para linguis melihat pentingnya teori tindak tutur sebagi sesuatu yang dapat diterapkan untuk mengatasi persoalaan-persoalan dalam sintaksis, sematik, dan belajar bahasa kedua (Sumarsono, 177:2010). Hal tersebut sejalan dengan Yule (2006:84) yang menyebutkan bahwa istilah tindak tutur umumnya diterjemahkan secara sempit dengan sekadar diartikan sebagai tekanan ilokusi suatu ukuran. Tekanan ilokusi sebagai ukuran adalah "apa yang diperhitungkan tekanan itu."

Austin dalam Chaer dan Agustina (2010:53) secara analitis membedakan tiga pristiwa tindakan yang berlangsung sekaligus, yaitu tindak tutur lokusi (iluctionary act); tindak tutur ilokusi (perloctionary act); dan tindak tutur perlokusi (perloctionary $a c t$ ). Tindak tutur lokusi adalah tindak tutur yang menyatakan sesuatu dalam arti "berkata" atau tindak tutur dalam bentuk kalimat yang bermakna dan dapat dipahami. Senada pendapat di atas, Chaer (2010:27) mengatakan bahwa tindak tutur lokusi adalah tindak tutur untuk menyatakan sesuatu sebagaimana adanya atau The Act of Saying Something tindakan untuk mengatakan sesuatu. Tindak tutur ilokusi adalah tindak tutur yang biasanya diidentifikasikan dengan kalimat performatif yang eksplisit. Hal tersebut sejalan dengan apa yang dikatakan Chaer (2010:28) yang 
menyatakan bahwa tindak tutur ilokusi selain mengatakan sesuatu juga menyatakan tindakan melakukan sesuatu. Oleh karena itu, tindak tutur ilokusi ini disebut The Act of Doing Something (tindakan melakukan sesuatu). Tindak tutur ilokusi ini biasanya berkenaan dengan pemberian izin, mengucapkan terima kasih, menyuruh, menawarkan, dan menjanjikan. Tindak tutur perlokusi adalah tindak tutur yang berkenaan dengan adanya ucapan orang lain sehubungan dengan sikap dan prilaku nonlinguistik dari orang lain itu.

Searle dalam Chaer (2010:29--30) membagi tindak tutur menjadi lima katagori, yaitu tindak tutur (1) representatif (disebut juga asertif), yaitu tindak tutur yang mengikat penuturnya kepada kebenaran atas apa yang dikatakannya. Misalnya, mengatakan, melaporkan, dan menyebutkan; (2) direktif, yaitu tindak tutur yang dilakukan penuturnya dengan maksud agara lawan tutur melakukan tindakan yang disebutkan di dalam tuturan itu. Misanyanya, menyuruh, memohon, menuntut, menyarankan, dan menantang. Hal tersebut sejalan dengan yang dikatakan Finnochiaro dalam (Sumarsono, 2010:
199) bahwa direktif mengarahkan, memberi pedoman, berusaha memengaruhi orang lain, mengajukan permohonan, menyarankan, meminta tolong, memperingatkan, minta petunjuk; (3) ekspresif, yaitu tindak tutur yang dilakukan dengan maksud agar tuturannya diartikan sebagai evaluasi mengenai hal yang disebutkan di dalam tuturan itu. Misalnya, memuji, mengucapkan terimakasih, mengkritik, dan menyelak; (4) komisif, yaitu tindak tutur yang mengikat penuturnya untuk melaksanakan apa yang disebutkan di dalam tuturannya. Misalnya, berjanji, bersumapah, dan mengancam; dan (5) deklarasi, yaitu tindak tutur yang dilakukan si penutur dengan maksud untuk menciptakan hal (status, keadaan, dan sebaginya) yang baru. Misalnya, memutuskan, membatalkan, melarang, mengizinkan, dan memberi maaf.

Mengacu kepada teori tindak tutur yang ada, dapat disimpulkan bahwa suatu bentuk ujaran dapat mempunyai lebih dari satu fungsi. Sebaliknya, satu fungsi dapat dinyatakan dalam berbagai bentuk ujaran. Prinsip kesopanan memiliki beberapa maksim yaitu maksim kebijaksanaan (tact maxim), maksim kemurahan (generosity 
maxim), maksim penerimaan ini menggariskan setiap peserta (approbation maxim), maksim pertuturan untuk meminimalkan kerendahan hati (modesty maxim), kerugian orang lain atau maksim kecocokan (agreement memaksimalkan keuntungan bagi maxim), dan maksim kesimpatian orang lain. Dalam hal ini, Leech (dalam (sympathy maxim). Prinsip kesopanan ini berhubungan dengan dua peserta percakapan, yakni diri sendiri dan orang lain. Diri sendiri adalah penutur dan orang lain adalah lawan tutur (Wijana, 1996:20). Ada beberapa bentuk ujaran yang digunakan untuk mengekspresikan maksim-maksim di atas. Bentuk ujaran yang dimaksud adalah bentuk ujaran impositif, komisif, ekspresif, dan asertif. Bentuk ujaran komisif adalah bentuk ujaran yang berfungsi untuk menyatakan janji atau penawaran. Ujaran impositif adalah ujaran yang digunakan untuk menyatakan perintah atau suruhan. Ujaran ekspresif adalah ujaran yang digunakan untuk menyatakan sikap psikologis pembicara terhadap sesuatu keadaan. Ujaran asertif adalah ujaran yang lazim digunakan untuk menyatakan kebenaran proposisi yang diungkapkan. Prinsip kesopanan mempunyai sejumlah maksim, yaitu:

a. Maksim Kebijaksanaan

Maksim ini diutarakan dalam tuturan impositif dan komisif. Maksim Wijana, 1996:30) mengatakan bahwa semakin panjang tuturan seseorang semakin besar pula keinginan orang itu untuk bersikap sopan kepada lawan bicaranya. Demikian pula tuturan yang diutarakan secara tidak langsung, lazimnya lebih sopan dibandingkan dengan tuturan yang diutarakan secara langsung. Pranowo (2009:122) mengatakan bahwa maksim kebijaksanaan mengamanatkan agar penutur selalu memberikan keuntungan pada mitra tutur ketika berkomunikasi.

b. Maksim Kemurahan

Maksim kemurahan menuntut setiap peserta pertuturan untuk memaksimalkan rasa hormat kepada orang lain dan meminimalkan rasa tidak hormat kepada diri sendiri. Maksim kemurahan diutarakan dalam tuturan ekspresif dan tuturan asertif. Tuturan ekspresif mempunyai fungsi untuk mengekspresikan, mengungkapkan, atau memberitahukan sikap psikologis sang pembicara menuju suatu pernyataan yang diperkirakan, misalnya mengucapkan selamat, 
mengucapkan terima kasih, memuji, menyatakan belasungkawa, dan sebagainya. Hal ini juga di ungkapkan oleh Tarigan dalam (Nadar, 2009:30) bahwa tuturan asertif melibatkan pembicara pada kebenaran proposisi yang diekpresikan, misalnya menyatakan, mengeluh, menyarankan, melaporkan, dan sebagainya. Dengan mengindahkan maksim ini, penutur harus sopan tidak hanya waktu menyuruh dan menawarkan sesuatu, tetapi dalam mengungkapkan perasaan dan menyatakan pendapatnya.

c. Maksim Penerimaan

Maksim penerimaan diutarakan dengan kalimat komisif dan impositif. Maksim ini mewajibkan setiap peserta tindak tutur untuk memaksimalkan kerugian bagi diri sendiri dan meminimalkan keuntungan diri sendiri. Maksim penerimaan diutarakan dengan tuturan komisif dan impositif. Maksim ini mewajibkan setiap peserta tindak tutur untuk memaksimalkan kerugian bagi diri sendiri dan meminimalkan keuntungan bagi diri sendiri. Chaer (2010:62) mengatakan bahwa maksim penerimaan dan maksim kerendahan hati adalah maksim yang berpusat pada diri sendiri. d. Maksim Kerendahan Hati

Maksim kerendahan hati berpusat pada diri sendiri. Maksim ini menuntut setiap peserta pertuturan untuk memaksimalkan ketidakhormatan pada diri sendiri dan meminimalkan rasa hormat pada diri sendiri. Pranowo (2009:111) menyatakan bahwa sifat rendah hati muncul karena adanya kesadaran individu maupun masyarakat bahwa setiap manusia memiliki kekurangan bawaan maupun kekurangan akibat pergaulan seseorang.

e. Maksim Kecocokan

Maksim kecocokan menggarisbawahi setiap penutur dan lawan tutur untuk memaksimalkan kecocokan di antara mereka dan meminimalkan ketidakcocokan di antara mereka.

f. Maksim Kesimpatian

Maksim ini diungkapkan dengan tuturan asertif dan ekspresif. Maksim kesimpatian mengharuskan setiap peserta pertuturan untuk memaksimalkan rasa simpati dan meminimalkan rasa antipati kepada lawan tuturnya. Jika lawan tutur mendapatkan kesuksesan atau kebahagiaan, penutur wajib memberikan ucapan selamat. Bila lawan tutur mendapat kesusahan atau 
musibah, penutur layak berduka atau mengutarakan bela sungkawa sebagai tanda kesimpatian.

Berdasarkan teori-teori yang telah dikemukakan, disimpulkan bahwa dalam berkomunikasi, prinsip kesopanan dan kesantunan sangat diperhatikan agar hasilnya nanti mitra tutur merasa disegani, dihormati, dan sebagainya oleh penutur, sehingga mitra tutur merasa nyaman ketika berkomunikasi. Akan tetapi, tidak hanya penututur yang harus memperhatikan beberapa maksim yang telah disebutkan di atas, mitra tutur juga harus memperhatikannya, sehingga dalam berkomunikasi prinsip kesopanan dan prinsip kesantunan itu terjalin antara penutur dengan mitra tutur.

\section{Metode Penelitian}

Jenis penelitian menggunakan deskriptif dengan pendekatan kualitatif. Data yang dikumpulkan berbentuk deskripsi percakapan antara peneliti dan pedagang. Bersifat deskriptif, karena data yang dikumpulkan berupa kata-kata, gambar, dan bukan angkaangka. Moleong dalam Muhammad (2002:19) menjelaskan bahwa metode penelitian kualitatif adalah metode penelitian yang menghasilkan data deskriptif berupa kata-kata tertulis atau lisan dari orang-orang dan prilaku yang dapat diamati. Penulisan deskriptif ini adalah jenis penulisan berdasarkan pembahasannya. Peneliti berusaha untuk memaparkan dan menguraikan secara deskriptif objektif tetang implikatur percakapan pedagang dan pembeli sayur dan barang yang lainnya di Pasar Mingguan Tebaban. Tempat penelitian yang peneliti pilih adalah Pasar Mingguan Tebaban Kecamatan Suralaga. Sampel dalam penelitian ini sebanyak 10 orang. Teknik pengambilan sampel menggunakan purposive sampling yakni pengambilan sampel dari populasi sesuai dengan tujuan penelitian.

Teknik pengumpulan data yang peneliti gunakan di dalam penelitian ini adalah pengamatan/observasi, cakap/wawancara, dan sadap/rekam. Dalam pengumpulan data, informan yang menjadi objek kajian tidak hanya penjual yang menggunakan bahasa Tebaban, tetapi juga meneliti bahasa di luar dialek Tebaban, mengingat penjual yang datang ke sana dari berbagai macam daerah, ada yang dari Sakra, Masbagik, Terara, dan lain sebagainya. Berbeda dengan pembeli, rata-rata 
pembeli/konsumen yang belanja di Pasar Mingguan Tebaban berasal dari daerah Kecamatan Suralaga yang menggunakan bahasa suralaga. Untuk kevaliditasan data, peneliti menggunakan teknik triangulasi data. Sugiyono (2011:241) mengemukakan "nilai dari teknik pengumpulan data dengan triangulasi adalah untuk mengetahui data yang diperoleh convergent (meluas), tidak konsisten atau kontrakdiksi. "Triangulasi data digunakan untuk memperkuat data agar datanya menjadi valid dengan cara data yang sudah didapat sebelumnya diperiksa dan dicocokkan kembali dengan melakukan pengamatan ulang kepada informan yang telah ditentukan, untuk mengecek apakah data yang telah diberikan kepada peneliti bersifat sementara atau belangsung pada setiap transaksi jual beli. Teknik analisis data dalam penelitian ini dilakukan melalui langkah-langkah yaitu transkripsi data, reduksi data, dan interpretasi data.

\section{Hasil dan Pembahasan}

Barlandaskan hasil penelitian di Pasar Mingguan Tebaban, peneliti mencari beberapa informan yang dijadikan sampel untuk mengatahui penerapan prinsip kesopanan yang terjalin antara penjual dan pembeli.
Untuk itu, peneliti melontarkan beberapa pertanyaan untuk memancing pengakuan dari informan-informan tersebut, diantaranya A (Peneliti) “... Yak pe merasa tersinggung ke misal na na ngeto pembeli no, lain bae ekspresi wajah na bareng bahasa na kurang sopan? (Apakah Anda tidak merasa tersinggung kalau pembeli seperti itu, ekspresi wajahnya sangat berbeda dan kurang sopan). Dari pertanyaan tersebut, informan memberikan informasi yaitu responnya terhadap bahasa yang digunakan oleh pembeli pada saat menawar ataupun membeli dagangannya dengan jawaban B (Partisipan) “... Yak na kumbe-kumbe angenku, wah biasa (Perasaan saya tidak apa-apa, sudah biasa). Mengacu pada komunikasi yang terjadi antara peneliti dengan informan tersebut, dapat disimpulkan bahwa informan tersebut tidak mempermasalahkan ucapan-ucapan yang dilontarkan oleh calon pembeli. Dari pernyataan tersebut, informan tersebut telah melaksanakan prinsip kesopanan yang mengacu pada maksim kebijaksanaan. Pedagang dalam hal ini mengedepankan maksim kebijkasanaan dalam komunikasi serta menghormati pembeli dan memberikan kebebasan 
kepada calon pembeli untuk jelas terlihat bahwa informan berusaha berkomunikasi. Artinya, pedagang tidak membatasi perkataan-perkataan dari calon pembeli dan seharusnya calon pembeli juga mengerti akan apa yang diinginkan oleh pedagang, tidak hanya memikirkan atau mementingkan keinginannya sendiri.

Berdasarkan analisis di atas, peneliti mencoba untuk menggali informasi lebih lanjut kepada informan-informan tersebut. Adapun informan yang peneliti wawancari yakni penjual dari Sakra yang memiliki dialek yang berbeda dengan pembeli. Adapun percakapan yang berlangsung yaitu A (Peneliti) “...Ngumbe tanggepan de si jeri pedagang lamune arak si nawar barang dagangan de sambilne lampaq? (Bagaimana tanggapan ibu sebagai pedagang jika ada calon pembeli yang menawar barang dagangan dengan cara berjalan?), dengan rasa penuh rendah diri informan memberikan pengakuan dengan ucapan B (Partisipan) “...Aroowah, ndek kembe-kembe lamun tiang jak, wah biase pembeli nawar sambil ne lampak... (Yaah, tidak apaapa kalau di saya sudah biasa pembeli menawarkan sambil jalan-jalan...). Dari pengakuan informan tersebut, menerima perlakuan dari calon pembeli walaupun sebenarnya dia merasa tersinggung dengan perbuatan yang dilakukan oleh calon pembeli yakni menawar barang dagangan dengan cara berjalan, seolah-olah calon pembeli tidak mempunyai adat istiadat, akan tetapi informan berusaha untuk menerimanya mengingat dia adalah seorang pedagang yang sangat membutuhkan kehadiran dari seorang pembeli. Pedanggan tidak mau ada konflik dengan konsumen, lebih-lebih tempat mereka jualan adalah tempat di mana desa konsumen itu sendiri, sehingga pedagang selalu menghormati dan mengalah kalau ada konflik dengan konsumen.

Selanjutnya, peneliti terus mencari informasi kepada informan tersebut dengan pertanyaan A (Peneliti) “...Endek-ndek de doang side jakne, endek ne kembe-kembe brembe maksud de? (Tidak apa-apa saja ibu ini, tidak apa-apa kenapa?). Informan pun memberikan jawaban yakni B (Partisipan) "Timak ape ke uni, endekne mele dengan, coba ape jak te uni jok pembeli?,,, (Emang saya harus bilang apa, orang tidak mau, saya harus bilang apa coba?). Berdasarkan 
pengakuan informan tersebut, dia mencoba untuk mengalah dari perlakuan pembeli agar tidak menimbulkan rasa dendam pada dirinya pribadi. Mengingat konsumen sangat diharapkan kehadirannya untuk membeli barang dagangannya. Percakapan pun terus berlangsung: A (Peneliti) "Endek ke de merese tersinggung ato ngembe?, karna kan adat ato kebiiasaan te no endekne cere ngeno ntan dengan?" (Tidakkah ibu merasa tersinngung atau apa? Karna adat dan kebiasaan kita tidak seperti itu cara orang...?). Informan pun menjawabnya dengan penuh kesabaran: B (Partisipan) “...Endek ke kembekembe angkak aku jakne, mun te empoh ne terusne endek mele jak, terus ape jak te uni? (Makanya tidak apa-apa kalau di saya, kalau sudah kita panggil terus dia tidak mau, kita mau bilang apa?). Dari pengakuan informan tersebut, dapat peneliti simpulkan bahwa informan tersebut telah melaksanakan prinsip kesopanan yang mengacu pada maksim kebijaksanaan. Dalam hal ini, informan tersebut berusaha menerima perlakuan calon pembeli. Pedagang memberikan keuntungan kepada calon pembeli ketika berkomunikasi. Hal seperti ini terjadi karena tidak adanya rasa empati pada diri calon pembeli tersebut. Pembeli hanya sekadar basa-basi saja menanyakan harga barang pedanggang tersebut atau bisa jadi ingin membandingkan harga dengan penjual yang lain.

Mengacu pada beberapa informasi atau penjual yang berasal dari Suralaga yang peneliti dapatkan dalam prinsip kesopanan, peneliti menemukan beberapa pengakuan dari informan, salah satunya yaitu A (Peneliti) “... Inaq, kumbe ke cara pe mun na arak pembeli rukat ngena "tono jak mudak na, tene jak mahal ia" (Ibu, gmana caranya kalau ada pembeli yang berkata "kalau di sana murah, di sini mahal"). Berdasarkan pertanyaan tersebut informan menjawabnya B (Partisipan) "Ado mun na mudaan tono jak, tono ka pe mbeli, lagu biasa na dengan rukat ngeto karena tono yak na muan mbli yak ampok na kte mbli atau nawar no" (Kalau lebih mudah di sana, ayo beli di sana kataku, karena nanti dia tidak dapat di sana makanya dia kembali ke sini..). Dari pengakuan informan tersebut, dapat peneliti simpulkan bahwa informan tersebut tidak terlalu banyak komentar dari perkataan-perkataan yang dilontarkan 
oleh calon pembeli untuk menghindari ketersinggungan pada dirinya. Itu sebabnya penjual menyuruh pembeli untuk kembali membeli barang di tempat yang murah menurut konsumen agar tidak terlalu terjadi banyak komentar dari pembeli. Menurut penjual, kalau terlalu dilayani dalam proses tawar menawar, akan terjadi konflik. Itulah sebabnya penjual tidak terlalu banyak komentar. Untuk memperjelas jawaban dari informan, peneliti kembali melontarkan pertanyaan untuk meyakinkan pendapat dari informan tersebut A (Peneliti) “.... Laguk yak pe tersinggung ke dengan ngkat-ngkat pembeli marak no-no?" (Tidakkah ibu tersinggung sebagai pedagang jika dia seperti itu?). Dengan singkat, informan merespon B (Partisipan) "Aok kah tono ka langan pe mbeli" (Ayo di sana dah tempatnya beli). Berdasarkan percakapan tersebut, dapat peneliti simpulkan bahwa informan tersebut tidak banyak omong ketika melakukan transaksi. Dari pengakuan tersebut, informan telah menjalankan prinsip kesopanan yang mengacu pada maksim kemurahan, informan merespon calon pembeli dengan kata-kata yang singkat, karena mungkin dengan cara tidak sengaja calon pembeli menyinggung perasaan informan dengan perkataan yang diucapkannya tersebut. Untuk itulah informan hanya menjawab sekadarnya saja.

Selanjutnya, peneliti mencoba bertanya kepada informan/penjual yang berasal dari Masbagik A (Peneliti) "Ngumbe ntan de inaq sikapin pembeli jaken de transaksi atau tawar menawar harga barang de lebih rendah atau ndek na sesuai kence harge sik wah tentuang de" (Bagimana caranya ibu menyikapi sikap pembeli ketika melakukan transaksi atau tawar menawar harga barang dagangan lebih rendah atau tidak sesuai dengan harga yang telah ditentukan?". Dari pertanyaan tersebut, informan memberikan jawaban yaitu B (pastisipan) "Aku sik nurunang harga" (Saya yang turunin harga). Berdasarkan pengakuan yang dilontarkan informan kepada peneliti, dapat disimpulkan bahwa informan tersebut telah melakukan prinsip kesopanan yang mengacu pada maksim penerimaan. Dalam hal ini, informan mencoba untuk meminimalkan keuntungannya sendiri agar barang dagangannya bisa cepat terjual dan tidak sampai dibawa pulang. 
Mengingat penjual sangat banyak dan lakunya barang itu juga sulit karena penjual yang lain juga menjual barang yang sama, penjual hanya untung sedikit, tidak sesuai dengan target harga barang.

Lebih lanjut, peneliti mencari informasi dengan melontarkan beberapa pertanyaan, di antaranya A (Paneliti) "Ngumbe prasaan de inaq jari pedagang lamun pembeli hanye ne nawar barang side doang laguk ndek nepayu beli? "(Bagaimana perasaan ibu sebagai pedagang jika calon pembeli hanya menawar barang dagangan akan tetapi tidak jadi untuk membelinya?").

Berdasarkan pertanyaan tersebut, informan menjawabnya B (Partisipan) “ (Ndek na gumbe-ngumbe, wah biase") "Tidak apa-apa, itu sudah biasa”. Berdasarkan pengakuan informan tersebut, dapat disimpulkan bahwa informan tersebut sudah biasa mendapakan perlakuan seperti itu dari calon pembeli, akan tetapi dia tidak mempermasalahkan perlakuan tersebut. Untuk itu, informan tersebut telah menjalankan prinsip kesopanan yang mengacu pada maksim kebijaksanaan. Dalam hal ini, informan tersebut mencoba memberikan keuntungan kepada mitra tutur atau calon pembeli agar calon pembeli tersebut merasa dihargai keberadaannya oleh pedagang. Akan tetapi, sering sekali calon pembeli tidak menyadari akan hal tersebut.

Berdasarkan pengakuan informan di atas, peneliti terus menggali informasi untuk memenuhi data yang peneliti harapkan. Salah satu percakapan yang berlangsung antara peneliti dengan informan yaitu A (Peneliti) ("Ngumbe pendapat cde inaq jari pedagang lamun calon pembeli ino nawar barang sambil ne lampak?”) ("Bagaimana tanggapan ibu sebagai pedagang apabila calon pembeli menawar barang dagangan dengan cara berjalan". Dengan singkat informan menjawabnya dengan $B$ (Partisipan) (Tiang kelek ie agar ne jok ite, ngeraos care solah-solah, lagi tetap doang ia lampak ndek ne siroang jok mudi) ("Saya penggil dia agar mendekat dan berbicara dengan baikbaik, tetapi tetap saja pembeli itu jalan tanpa melihat ke belakang lagi”).

Berdasarkan pengakuan informan tersebut, terlihat bahwa dia tidak terlalu mengharapkan pembeli yang seperti itu sehingga informan berlaku agak cuek dan hanya berkata sekadarnya. Dari 
informasi yang diberikan informan tersebut, peneliti melontarkan pertanyaan lanjutan yakni dengan menggunakan bahasa sasak “...Misalnya denger ia denger, arak ke pengalaman pe na tulakin lek penjual? (Misalkkan dia dengar, tidak pernah ada pengalaman dia balik lagi kepada $i b u$ ?). Berdasarkan pertanyaan tersebut, informan memberikan jawaban berupa “Pe kete ka, girang pe nawa-nawar sambil lekak,) (Ayo berhenti, kenapa nawar-nawar sambil jalan, kataku). Dari jawaban informan tesebut, peneliti dapat menarik simpulan bahwa ketika berdagang, pedagang tidak terlalu memanjakan atau meladeni satu calon pembeli saja, tetapi berusaha untuk tidak terlalu memperhatikannya agar calon pembeli merasa bahwa dia juga membutuhkan pedagang, bukan pedagang saja yang membutuhkan pembeli. Berdasarkan informasiinformasi yang diberikan informan, peneliti semakin ingin mengatahui bagaimana cara informan ini menyikapi calon pemebeli ketika pada saat bertransaksi jual beli ternyata pembeli tidak jadi membeli barang tersebut. Adapun pertanyaannya yaitu “... Laguk, mun na urung dengan belanja, kumbe tanggapan pe? (Tetapi, nanti tidak jadi dia belanja, bagaimana tanggapannya ibu?"). Dari pertanyaan tersebut, informan menjawabnya dengan rada-rada pesimis "Yak na kumbe-kumbe, kan jak hak dengan..." (Tidak apa-apa, biarkan sudah hak orang...). Dengan rasa rendah diri, informan berusaha untuk menerima perlakuan dari calon pembeli mengingat posisinya hanyalah sebagi pedagang. Peneliti pun melontarkan pertanyaan lanjutan untuk semakin memperkuat pendapat dari informan tersebut dengan pertanyaan " Mule ngeto pendait ta mun ta jari pedagang setiap hari ke? (Memang seperti itu yang dihadapi setiap harinya ya?). Dari pertanyaan tersebut, informan pun membarikan jawaban "Aok, mule ia wah mun ta jari pedaggang jak" (Ya, memang seperti itu cara kita sebagi pedagang).

Mengacu pada percakapan yang terjadi antara peneliti dengan informan di atas, dapat peneliti simpulkan bahwa hendaknya sebagai seorang pedagang tidak cepat merasa tersinggung atau marah dengan segala perlakuan yang dilontarkan oleh calon pembeli. Kalau pedagang cepat marah, jarang orang yang mau belanja terhadapnya. Untuk itu, pandai-pandailah mengambil 
hatinya orang dalam berkomunikasi. Dari percakapan tersebut, informan telah menjalankan prinsip kesopanan yang mengacu pada maksim penerimaan. Dalam hal ini, informan mencoba untuk meminimalkan perannya sebagai pedagang. Artinya, informan tersebut tidak mementingkan egonya, akan tetapi lebih memerhatikan calon pembeli. Dalam kasus ini, informan sadar akan perannya yang menjadi pedagang untuk memenuhi kebutuhan hidup diri dan keluarganya.

Penelitian selanjutnya tentang A (Ongkat pembeli sik ngumbe mbeng cde tersinggung ianq sik jari pedagang") (Tuturan dari pembeli yang seprti apa yang dapat menyinggung perasaan ibu sebagai pedagang?). Dari pertanyaan tersebut, informan menjawabnya B ("Ngete ngkat na "tono jak mauq ita 5 buah harga ne 1.500" Aok tono ka pe mbeli (Begini katanya, kalau di sana dapat kita 5 harga 1.500. ya ke sana kamu beli)". Berdasarkan pengakuan informan tersebut, jelas terlihat bahwa dia tidak senang jika ada yang membanding-bandingkan barang dagangannya dengan barangnya orang lain. Tetapi, berkat pengalamannya selama berdagang, dia mencoba untuk menerima perkataan yang diberikan kepadanya. Untuk itu, informan tersebut telah menjalankan prinsip kesopanan yang mengacu pada maksim kebijaksanaan. Dalam hal ini, informan tersebut berusaha untuk menerima perkataan-perkataan dari calon pembeli yang dapat menyinggung perasaannya sebagai pedagang.

Percakapan selanjutnya dalam penelitian selanjutnya yaitu A “Jari na ketimbang da rugi, araan ke pe antik barang pe ulek dakak na masih penok? (Jadinya dari pada ibu rugi, lebih baik barangnya dibawa pulang biarpun masih banyak?, informan pun menjawabnya B “Araan so, ahparo jak kadang-kadang lamun na sepi lalo pembeli jak jual ku ia yang penting na laku” (Lebih baik seperti itu, atau kadang-kadangkalau sudah terlalu sepi yang penting laku, saya jual). Berdasarkan jawaban informan, tersebut jelas bahwa dia berusaha untuk meminimalkan keuntungannya sebagai pedagang agar barang dagangannnya bisa habis terjual. Karena, semakin lama barang itu tidak dibeli oleh pembeli, akan membuat barang tersebut menjadi tidak bagus, mengingat barang-barang jenis dan 
model baru bermunjulan dan dengan (pembeli) mbeng epe mengalahkan barang yang sudah lama, tersinggung jari pedagang?" (Apa kata sehingga dijual dengan harga yang murah walaupun rugi sedikit. Peneliti yang sering diucapkan orang yang dapat menyinggung perasaan ibu pun melanjutkan pertanyaan yakni A sebagai pedagang?). Informan (“Jual modal wah tuka juluk?” (jual menjawab B "Girang na bandingang modal dah dulu), dengan rasa rendah diri informan menjawabnya B "Ngeto harga barang ta kenca barang dengan” (Sering membandingwah juluk, lagu mun ta jual sayur jak harus ne laku, mun yak jak loas ia (Bisa dibilang begitu, tapi kalau jual sayur harus dia laku, kalau tidak akan rusak). Dari pengakuan informan tersebut, terlihat bahwa dia sangat membutuhkan pengartian dari calon pembeli agar perkataan-perkataan yang diucapkan oleh informan bisa menjadi bahan pertimbangan ketika melakukan transaksi sebelum menemukan kata sepakat. Tetapi, kadang pembeli tidak memahami perkataan ini sehingga pembeli tidak jadi membeli barang dagangan yang dijual. Apalagi pedagang jual sayuran, harapan mereka sayuran itu bisa laku semuanya tanpa ada sisa, walaupun dijual murah.

Lebih lanjut, peneliti mendapatkan informasi akan prinsip kesopanan yang terjadi antara penjual dan pemebeli sayuran yang ada di Pasar Mingguan Tebaban. Adapun salah satu percakapannya yaitu A "Ape ngkat bandingkan barang saya dengan barangnya orang). Berdasarkan pengakuan informan tersebut, sangat jelas terlihat bahwa dia tidak suka jika ada orang membanding-bandingkan barang dagangannya dengan barang dagangan orang lain.

Hal ini sangat menggangu pikiran dan perasaan penjual. Peneliti terus memancing pengakuan-pengakuan dari informan tersebut. Adapun pertanyaannya adalah A "Bandingbandingan kumbe maksud pe? (Banding-bandingin kayak bagaimana maksudnya ibu?). Dari pertanyaan tersebut, informan menjawab B “Girang na nyebut-nyebut ngena "tono jak beruk mudaan aji na, tene jak ndrak bau ta regak" marak-marak nono wah. (Sering dia nyebut-nyebut, katanya "tadi di sana lebih murah, tapi sekarang di sini tidak bisa ditawar", sejenis itu sudah). Jika peneliti perhatikan pengakuan-pengakuan dari 
informan tersebut, dia sangat merasa tertekan dengan perkataan dari calon pembeli yang membanding-bandingkan dirinya dengan orang lain, sehingga informan sedikit mengacuhkan perkataan dari calon pembeli tersebut. Berdasarkan pengakuan informan tersebut, peneliti melontarkan pertanyaan lanjutan yakni B "Terus, kumbe tanggapan pe mun na rukat ngeto no? (Terus, bagaimana tanggapan ibu terhadap orang itu?). Informan pun menjawab B "apa $k a$ tuka, tdoak doang, aran jak ta meta rizki”.. (yaaa saya mau bilang apa, saya diam saja, namanya aja kita mencari rizki). Berdasarkan jawaban tersebut, terlihat bahwa informan berusaha untuk merendahkan diri sebagai seorang yang sangat membutuhkan kehadiran dari seorang pembeli yang dapat mendatangkan rizki bagi dirinya. Untuk memperkuat pengakuan dari informan tersebut, peneliti melontarkan pertanyaan susulan A "Yak pe suru ia mbeli langan lain pin langan paran na mudaan no? (Tidak ibu suruh dia beli di tempat yang dia bilang lebih murah itu?). Dari pertanyaan peneliti tersebut, informan menjawab B "Yak, tedok doang, belagak cuek timak jak sebenarnya sakit angen ta. (tidak, saya diam saja, berlagak cuek, walaupun sebenarnya hati saya sakit).

Berdasarkan percakapan tersebut, informan berusaha untuk memendam keinginan hatinya yang bisa saja sakit oleh perkataan-perkataan yang dilontarkan calon pembeli agar tidak terjadi ketersinggungan dan kesalahpahaman di antara penjual dan pembeli. Pengakuan tersebut juga bisa terucap dari informan tersebut karena memang banyak sekali calon pembeli yang mengacuhkan keberadaannya sebagai pedagang. Untuk itu, dapat peneliti simpulkan bahwa informan tersebut melaksanakan prinsip kesopanan yang mengacu pada maksim kerendahan hati. Dalam hal ini, informan beusaha menerima perbandingan-perbandingan yang dilontarkan oleh calon pembeli karena informan tersebut menyadari bahwa setiap individu memiliki kekurangan dan kelebihan masingmasing.

Percakapan terahir dalam penggalian informasi mengenai prinsip kerjasama yaitu B “Kumbe perasaan pe mun na arak dengan belanja langgar prinsip kesopanan berbahasa? (Bagamana perasaan ibu kalau ada orang yang melanggar prinsip 
kesopanan berbahasa?). Informan pun menjawab

B "Pasti ta kecewa" (Pastinya saya kecewa). Dari jawaban informan, disimpulkan bahwa dirinya kecewa jika ada orang yang melanggar prinsip berbahasa. Seharusnya, walaupun kita berada di pasar, hendaknya kita tetap menjaga bahasa yang kita gunakan agar tidak terjadi ketersinggungan antara lawan tutur (pedagang) ataupun mitra tutur (calon pembeli). Berdasarkan pengakuan tersebut, peneliti terus menggali informasi kepada informan tersebut: A "Kumbe cara pe respon dengan ngeto no? (Bagaimana cara ibu menyikapinya kalau yang seperti itu?). Dengan rasa percaya diri, informan menjawab B "Tergantung dengan no, kadang-kadang dengan na ngeto no, peringatinku ia agar yak na singgung perasaan pedangng lain na. (Tergantung rupa orangnya, terkadang kalau orangnya bagaimanaa gitu, saya peringati agar dia tidak sampai seperti itu, yang dapat menyinggung perasaan pedagang lain). Bardasarkan jawaban informan tersebut, jelas terlihat bahwa rasa kemanusiaan itu tetap terjalin sehingga dalam hal ini, informan mencoba untuk saling memperingati jika ada perkatan atau ucapan yang salah agar nantinya tidak terjadi kesalahan berbahasa ketika berkomunikasi dengan orang lain.

Mengacu pada percakapan yang terjadi antara peneliti dengan informan di atas, dapat peneliti simpukan bahwa dalam bermasyarakat, hendaknya kita saling memperingati sebagi orang yang peduli terhadap sesama, sebagaimana yang terjadi pada informan tersebut. Dalam hal ini, informan mencoba untuk memperingati calon pembeli agar dalam berkomunikasi hendaknya bahasanya diatur atau disesuaikan dengan siapa dan di mana dia berkomunikasi. Untuk itu, informan tersebut tengah menjalankan prinsip kesopanan yang mengacu pada maksim kerendahan dan kemurahan. Dalam hal ini, informan menyadari bahwa kita hidup di lingkungan yang berbedabeda, tentunya dengan bahasa dan budaya yang berbeda-beda pula. Untuk itu, informan berusaha untuk memperingati mitra tutur (calon pembeli) agar nantinya ketika berhadapan dengan orang lain, mitra tutur tesebut bisa menyesuaikan bahasa yang digunakan. 


\section{Penutup}

Berdasarkan hasil analisis terhadap kajian prinsip kesopanan yang terjadi antara penjual dan pembeli sayuran di Pasar Mingguan di Desa Tebaban, peneliti dapat menarik simpulan bahwa prinsip kesopanan tidak hanya bisa terjadi pada penjual, tetapi terjadi juga pada pembeli. Adapun jumlah maksim yang muncul pada prinsip kesopanan antara penjual dan pembeli sebanyak 14 maksim, di antaranya maksim kemurahan sebanyak 5 data, maksim kebijaksanaan sebanyak 4 data, maksim penerimaan sebanyak 3 data,

\section{Daftar Pustaka}

Aslinda \& Syafyahya, Leni. (2010). Pengantar Sosiolinguistik. Bandung: Refika Aditama.

Chaer, Abdul \& Agustina, Leoni. (2010). Sosiolinguistik Perkenalan Awal. Jakarta: Rineka Cipta.

Chaer, Abdul. (2010). Kesantunan Berbahasa. Jakarta: Rineka Cipta.

Louise, Cummings. (2007). Pragmatik Sebuah Perspektif Multidisipliner. Yogyakarta: Pustaka Pelajar.

Muhammad. (2002). Paradigma Kualitatif Penelitian Bahasa. Yogyakarta: Liebe Book Press. dan maksim kerendahan hati sebanyak 2 data. Berdasarkan data tersebut, maksim yang paling sering muncul yaitu maksim kemurahan dan maksim yang jarang mucul yaitu maksim kerendahan hati. Dalam menerapkan prinsip kesopanan antara penutur dan lawan tutur, ditutut saling menghormati dan menghargai serta menjunjung tinggi prinsip kesopanan agar pelaku tutur pada saat itu tetap saling mengerti dan memahami makna tuturan pada saat berkomunikasi/berinteraksi.

Nadar, F. X. 2009. Pragmatik \& Penelitian Pragmatik. Yogyakarta: Graha Ilmu.

Sugiyono. (2011). Metode Penelitian Kuantitatif Kualitatif dan $R \& D$. Bandung: Alfabeta.

Sumarsono. (2010). Pragmatik. Singaraja: Universitas Pendidikan Ganesa.

Pranowo. (2009). Berbahasa Santun. Yogyakarta: Pustaka Belajar.

Wijana, I Dewa Putu. (1996). DasarDasar Pragmatik. Yogyakarta: ANDI.

Yule, George. (2006). Pragmatik. Yogyakarta: Pustaka Belajar. 